This is the post print version of the article, which has been published in Discourse \& Society 2015, 26(1), pp 113-132.

DOI: $10.1177 / 0957926514543229$

[2] This document has been downloaded from TamPubutafi The Institutional Repository of University of Tampere

\title{
Producing gendered parenthood in child health clinics
}

\section{Sanni Tiitinen and Johanna Ruusuvuori}

University of Tampere, Finland

\begin{abstract}
This study examines whether and how equally shared parenting or gendered parenthood is produced in and through institutional interactions between professionals and parents in preventive child health clinics in Finland. The data consists of 17 video-recorded encounters in child health clinics between parents and public health nurses, and the method is conversation analysis. The analysis indicates that the primacy of mothers as parents is typically presupposed by participants when they discuss topics related to shared parenting. However, we also demonstrate that in many cases participants deviate from the presuppositions of gendered parenthood. We discuss our results with regard to questions of how institutional and cultural understandings of parenthood are co-constituted in talk-ininteraction, and how institutional interaction may provide an arena for negotiating these understandings.
\end{abstract}

\section{Keywords}

Child health clinics, conversation analysis, fathers, gender, mothers, parenthood, presuppositions, public health nurses

\section{Introduction}

Previous studies on the construction of parenthood have demonstrated the existence of two discourses of parenthood: one that represents parents as equal and as sharing childcare responsibilities, and another that represents the mother as the principal parent with the father playing a secondary role in childcare (Lazar, 2000; Sunderland, 2000, 2006; Vuori, 2009). In these discursive studies data has included magazines (Sunderland, 2006) and literature aimed at parents (Sunderland, 2000), advertisements (Lazar, 2000) and writings by family professionals (Vuori, 2009). In addition, the existence of both enduring and new cultural ideals about parenthood - for example, more involved fatherhood - has been analysed extensively, using interviews with parents as data (e.g. Barclay and Lupton, 1999; Henwood and Procter, 2003; Nentwich, 2008; Perälä-Littunen, 2007; Sevón, 2011). 
In this study we analyse whether and how equally shared parenting and gendered parenthood are produced in and through institutional interactions between professionals and parents in preventive child health clinics in Finland. The data consists of 17 video-recorded encounters in child health clinics between parents and public health nurses. Using conversation analysis (CA) we demonstrate that the primacy of mothers is typically presupposed by the participants. In addition, we present cases in which the participants deviate from this gendered presupposition.

The focus on gendered presuppositions about parenthood in child health clinics in Finland offers a particular context for the study. The policy ideals of reconciling paid work and family life and enhancing gender equality in parenting have been manifested for example through state-sponsored childcare services and paid parental leaves to which both parents are entitled (Leira, 2002: 81-85). A recent development has been the introduction of a nontransferable parental leave for fathers (Lammi-Taskula, 2008: 136; Leira, 2002: 85). The policy ideal of shared parenting is an emerging rather than an established discourse. Family professionals (Eräranta, 2005; Vuori, 2009) and laypeople alike have diverse and sometimes ambivalent ideas about parenthood (Perälä-Littunen, 2007). Although shared parenting is typically seen as important, the role of fathers of babies is especially disputed (Vuori, 2009: 45). Numerous Finnish research reports have also demonstrated that while there have been changes of practice in relation to parental leave, mothers take the vast majority of leave periods (Haataja, 2009: 16; Lammi-Taskula, 2008: 134) and spend significantly more time than fathers on housework and childcare (Miettinen, 2008: 51; Official Statistics of Finland, 2011).

Professionals in child health clinics in Finland are also advised to inform parents about the benefits of shared parenting (Ministry of Social Affairs and Health, MSAH, 2004: 84). Maternity and child health clinics are a free public service for all expectant parents and for families with children under the age of six years. These services are widely used, and almost all families with children visit the clinics (MSAH, 2004: 18). This study presents a detailed analysis of segments of interaction between public health nurses and parents in child health clinics during which the participants discuss topics related to shared parenting. Our starting point is that face-to-face interaction provides an arena in which presuppositions of parenthood are co-constituted and negotiated.

\section{Data and analysis}

The data was collected as a part of a multidisciplinary research project in maternity and child health clinics in a medium-sized town in Finland during 2006-2008. The analysis is based on the 17 video-recorded encounters in child health clinics in which both parents are present, out of a total collection of 143 encounters in maternity and child health clinics. All the couples are heterosexual. In addition to the parents, the parties present are a public health nurse and a baby aged $0-1$ years. Occasionally an older sibling or an intern may also be present. The data was video-recorded in five different child health clinics with eight different public health nurses. The duration of the encounters ranged from 25 minutes to over one hour, and there were approximately 11 hours' data in total. The ethics board of the city overseeing the clinics gave permission for the data collection. All participants gave their informed consent to the video-recording. 
We have identified all the topical segments $(n=43)$ in which the participants explicitly address topics related to shared parenting: sharing childcare or household tasks, taking parental leave, combining paid work and family life, and the father's participation during childbirth. In most cases one of these topics is invoked in the nurse's topic-opening question, but there are also some cases in which the parents initiate the topic in their responsive or topic-opening turns. According to the data, most if not all of the mothers in these encounters are on maternity or parental leave. The fathers are working, studying, or on paternity leave or holiday at the time of the encounter.

Using conversation analysis, we focus on the interactional practices through which participants make sense, understand and organise their actions and the social world around them (Heritage, 1995; Pomerantz and Fehr, 1997). A point of departure that is especially relevant for this study is that all the participants in these encounters can be characterised by various categorisations, dealing with for example gender, age or occupation. While such characterisations may be valid, the participants need not orient to them as relevant for the ongoing sequence of interaction. (Schegloff, 1997: 165-168.) We characterise the participants in our data as (public health) nurses, mothers and fathers. These category terms have been chosen because they are the institutional roles on the basis of which the participants have arrived at the encounter, and also because the category terms 'mother' and 'father' are one way that nurses refer to their clients during these encounters.

However, the gendered roles of mothers and fathers are not intrinsically relevant for the participants during the encounters. Rather, participants' orientations to such gendered expectations concerning parenting become observable in the minute practices of talk-ininteraction (Kitzinger, 2006: 74-78; see also Kitzinger, 2000, 2005, 2008). Participants display their understanding of institutional and cultural norms and invoke presuppositions, for example by designing their questions in certain ways (Heritage, 2010: 47-48; Lindfors and Raevaara, 2005: 142), or by treating something as surprising (Kitzinger, 2006: 71-75), accountable or newsworthy. These practices are our focus in this article. We have collected the nurses' questions, advices and topicalising turns in the topical segments on which we focus and analysed how they invoke presuppositions about parents' actions. We have also analysed how the parents orient to these presuppositions in their responsive turns and invoke presuppositions about parenthood when initiating the topic related to shared parenting. In addition to the practices of invoking and orienting to presuppositions about parenthood, we are interested in what sorts of presuppositions are made.

\section{Co-constituting gendered parenthood}

The following analysis describes the ways in which the role of fathers as parents is produced as secondary when compared to mothers. In their questions and other types of turns, nurses typically treat childcare by mothers as self-evident, while childcare by fathers is treated as expected to some extent but not as self-evident. In addition, parents may upgrade or initiate the presupposition of mothers' primacy in relation to responsibilities for childcare. First we present the former cases, and then the latter. 


\section{Nurses' turns invoke presuppositions of gendered parenthood}

The following two extracts illustrate some of the ways in which presuppositions of gendered parenthood are invoked in the nurses' turns. A typical practice of initiating talk about sharing parental responsibilities in our data is topicalising the father's role in childcare. In Extract 1, the nurse first topicalises the father's role in childcare and designs her question to treat the mother's taking care of the baby as self-evident. Moreover, she normalises the father's secondary role in childcare. At the beginning of the extract the nurse and the mother are discussing whether the parents have been able to sleep properly. The mother says at lines 4-6 that during the two weeks (referring to the time the father is on leave, which has been mentioned previously during the encounter) they have been taking turns, with the father being prepared to comfort the baby during the night. We focus on the nurse's turns at lines $9,11,15$ and 18 , indicated with arrows. (In the extracts, $\mathrm{N}=$ public health nurse, $\mathrm{M}=$ mother, $\mathrm{F}=$ father, $\mathrm{B}=$ baby. The first line shows the original in Finnish and the second line the idiomatic translation into English. In the lines on which we are focusing we also provide a middle line indicating the word order in Finnish. A key to the transcription symbols is given in the appendix.)

\section{Extract 1 (ch3, baby five months old)}

(( $\mathrm{M}$ is changing the nappy; $\mathrm{N}$ is standing next to the baby-care table and $\mathrm{F}$ is walking towards it))

$3 \quad \mathrm{~N}: \quad((\ldots))$ saatte kohtuudella [nukkua että, ((...)) you get to sleep [reasonably so,

M:

[Juu ja nyt varsinki tää pari viikkoa ny (.)

[Yes and especially now these two weeks now (.)

vuorotellen aina ollaan sit niinku vähä siinä (0.3) valmiudessa we have been taking turns all the time in like being somewhat (0.3) prepared

et toinen on sitte se joka laittaa sitä tuttia tai jotain ja so that the other one is then the one who puts in the dummy or something and

$7 \quad \mathrm{~N}:(\mathrm{Mm}$,

$8 \quad \mathrm{M}:(\operatorname{nou}[\mathrm{see})(-)$ (gets [up) (-)

$9 \quad \mathrm{~N}: \rightarrow \quad$ [Herääk sääki (.) äänte ${ }^{\circ} l y y .^{\circ}$ wake.up-Q you-SG.also to.sounds

[Do you also (.) wake up because of sou ${ }^{\circ}$ ds $(($ made by the baby $)) .^{\circ}(($ gazes at F $))$ 
$11 \mathrm{~N}: \rightarrow$ Ook sää [herkkäuni-

are-Q you-SG a.light.sleep(er)

Are you [a light sleep-

12 F:

$[<$ Emmää [oikeestaan $>$ Kyllä se usein

$[<$ Not [really $>$ It is in fact often

13 M:

[Ei kauheen (-)

[Not very (-)

14 F: sillai että Mari sitte tönii mua [että (0.3) katos ny että se (0.5)

so that Mari then pushes me [so that (0.3) look now he (0.5)

$15 \quad \mathrm{~N}: \rightarrow$

$[£ \mathrm{Ni}(\mathrm{h})$ heh heh£

$[£ \operatorname{Yeah}(\mathrm{h})$ heh heh£

$16 \mathrm{~N}: \quad[£$ Aiva.£

[£Right.£

$17 \quad \mathrm{M}: \quad[($ Inisee $)$

$[$ (Whimpers)

$18 \mathrm{~N}: \rightarrow £$ Nii, $=[$ Aika monessa perh(h)eessä se (.) kuvi[o(h) (on nii.)£

£Nii, $=[$ In quite many famil(h)ies the (.) pat $[\operatorname{tern}(\mathrm{h})$ (is like that.)£

19 F:

[Mää

[I

[En mä viime yönäkää sitä kyllä

[I didn't even last night in fact

20 F: huomannu että se ähisteli ${ }^{\circ}(\text { että })^{\circ}$

notice that he was groaning ${ }^{\circ}(\mathrm{so})^{\circ}$

$(0.6)$

M: ${ }^{\circ}(\mathrm{Mm})^{\circ}$ (no niin ku) sä nukut sit vähä

${ }^{\circ}(\mathrm{Mm})^{\circ}$ (well that's because) you sleep then a little more

kauempana sillon (1.4) sillon ku on mun vuoroni heräillä?

far away when (1.4) when it is my turn to wake up?

((talk about nights continues))

The nurse addresses question 'do you also wake up because of sounds [made by the baby]' (line 9) to the father by gazing at him (Sacks, Schegloff and Jefferson, 1974: 717). This question topicalises the father's role during the night: although the mother has just stated that they have both been prepared to comfort the baby if he wakes up at night, the question treats the father's waking up as newsworthy and not self-evident. The question also includes elements that treat the mother's waking up as self-evident: the nurse emphasises the pronoun 
'you' referring to the father and uses the clitic '- $k i$ ' (translated as 'also'), and in this way highlights that the possibility of not waking up is related only to the father.

The question (line 9) is followed by a 0.4 second silence, indicating a dispreferred answer: the father does not wake up. Accordingly, the nurse reformulates the question (line 11) to make it less accountable for the father by shifting the focus away from his actions and towards a benign characteristic (being a light sleeper). The reformulated question presents a legitimate reason for the father not waking up: he will wake up only if he is a light sleeper.

The nurse's way of receiving the father's answer further demonstrates that his secondary role at night is treated as normal. The father reports that the mother wakes him (lines 12 and 14), and the mother confirms this by completing his turn with the verb 'whimper' (line 17). The nurse receives the description with the particle 'nii' (lines 15 and 18), which displays recognition of the situation (Sorjonen, 2001: 164). At line 18, she presents the situation under discussion as normal, a typical pattern in other families as well. By laughing at line 15 and using a smiley voice at line 18 , the nurse softens the accountability invoked by her question and implies that the division of labour in the family is non-problematic.

At line 19, the father continues to narrate that he had not noticed when the baby had been groaning during the previous night. After this (line 22), the mother initiates an account for the father's behaviour during the previous night: it was her turn to wake up, and therefore the father was sleeping further away from the baby. Thus she treats the father's secondary role as accountable, at least in terms of consistency with her previous description of 'being prepared' to take care of the baby.

Extract 2 presents another example of nurses' ways of invoking presuppositions about gendered parenthood. As in Extract 1, the nurse topicalises the father's role in childcare with yes/no questions. Further, she treats the mother's being away from the baby as accountable. Both the father and the mother are on parental leave at the time of this encounter. Before the beginning of the extract, the mother and the nurse have been talking about the possibility of giving the baby some formula or of pumping breast milk. The mother has been breastfeeding the one-month-old baby, and now she has asked for advice on how to deal with the situation, as she has some (unspecified) plans which mean that she will be away from the baby for a while. We focus on the nurse's turns at lines 4, 8 and 10-11.

\section{Extract 2 (ch2, baby one month old)}

$1 \quad \mathrm{~N}: \operatorname{Mm}[(\mathrm{mm})$

2 M: $\quad$ [Voihan sitä testata kyllä sitte $\left[{ }^{\circ}\left(\right.\right.$ kuitenki) ${ }^{\circ}$ [You can just test it then $\left[^{\circ}(\text { anyway })^{\circ}\right.$

$3 \quad \mathrm{~N}:$

[Joo, [Yes,

$4 \quad \mathrm{~N}: \rightarrow=$ Isä jää hoitamaan

$$
\begin{aligned}
& { }^{\circ} \text { sitte }[\text { niinkö } \\
& \text { then so-Q }
\end{aligned}
$$$$
\text { father stays to.take.care }
$$

$=$ Father stays to take care $\left(\left(\right.\right.$ of the baby)) ${ }^{\circ}$ then [is it so ${ }^{\circ}$ 
$6 \mathrm{~N}:$ Joo,

Yes,

7

$(0.3)$

$8 \mathrm{~N}: \rightarrow$ Ootteko te ollu kaksin, have-Q you-PL been by.yourselves

Have you two been alone,

(1.1) ((N gazes at F; M gazes at N; F's gaze not visible $))$

Before so that (.) you two are alone at ho $\uparrow \mathrm{me} \uparrow$ and (.)

$11 \rightarrow$ äiti £on ollut heh 1(h)iikenteessä että?£

mother has gone.out so

the mother £has gone heh ou(h)t so?£

$\mathrm{F}: \quad[\mathrm{Juu} \uparrow::$ siis ollaan. [Ye $\uparrow::$ s I mean we have.

13 M: [No mä oon käyny jossain Sitta]ris[sa ja tommosissa [Well I have been to a super]ma[rket and things like that

$14 \mathrm{~N}$ :

$[£ N i i, £$

$[£$ Yes, $£$

$15 \mathrm{M}:$ mutta (0.2) en mä kauheen pitkiä aikoja et

but (0.2) I haven't ((been away)) for very long times as

16 M: [sitte niinku (.) silleen että ku on syöttäny ni ((...))

[then you know (.) like when you have breastfed ((...))

$17 \mathrm{~N}: \quad[$ Joo.

[Yes.

As in the previous extract, at line 4 the nurse topicalises the father's role in childcare. The question 'father stays to take care [of the baby] then is it so' continues the topic of taking care of the baby when the mother is away by introducing another condition - in addition to feeding the baby - for the mother's plans. The grammatical design of the question as a yes/no declarative invokes a presupposition (see Heritage, 2010: 47-49) that the father takes care of the baby when the mother is away. However, the presupposition is weakened by the tag 'niink ö' ('is it so') and the particle 'sitte' with which the nurse marks the question as an inference from previous talk (VISK, §825). The inference is not, however, drawn directly from the previous discussion, as the parents have not mentioned anything about the father's 
actions when the mother is away. Nevertheless, the mother has referred to her not their plans, and thus the father's presence has not been ruled out either. In sum, the question treats the father as a probable carer for the baby while the mother is not present, but it also suggests that this is not self-evident.

The second question from the nurse, 'have you two been alone' (line 8), topicalises the father's role in childcare more generally. By gazing at the father at the end of the question the nurse addresses him as the respondent (Sacks, Schegloff and Jefferson, 1974: 717). As a yes/no interrogative the question suggests that it is not self-evident that the father has been alone with the baby so far (see Heritage, 2010: 47-49).

The nurse's subsequent elaboration of the question treats the mother's being away from the baby as accountable. The initial question is followed by a long silence (line 9), which indicates that the parents have some difficulty in answering the question. The nurse treats the silence as the result of some trouble in understanding arising from the non-specificity of her question, clarifying it with an utterance which is grammatically a fluent continuation of her question (lines 10-11). The nurse clarifies that 'you two' refers to the father and baby staying at home when the mother is away. The nurse's laughter, accompanied by the word 'liikenteess ä' (an idiomatic expression for 'going out'), suggests the delicacy of the issue of the mother's being away from her one-month-old baby (see Haakana, 2001).

Interestingly, the parents orient to the nurse's elaborated question differently (cf. Heritage and Sefi, 1992: 367). The father answers the question only after the nurse's clarification, and his answer 'yes I mean we have' (line 12) displays an understanding of the referents of the question. The mother orients to the delicacy of being away from the baby by explaining that she has only been to a supermarket and not for long. She also highlights that she takes care of the baby's needs before going to the supermarket by acknowledging that she breastfeeds the baby first (line 16). (Her account is not given in full in the extract.)

The above two extracts have illustrated the ways in which nurses' turns invoke presuppositions of gendered parenthood. In both extracts, the nurse topicalises the father's role in childcare with yes/no questions. The recurrent practice in our data of topicalising the father's role and the way in which these questions are designed suggest that childcare by fathers is treated as possible and appropriate, but not as self-evident like childcare by mothers.

\section{Parents upgrade the gendered presuppositions}

Next we turn our focus to cases in which parents upgrade the gendered presuppositions invoked by nurses. A detailed analysis of parents' responses highlights a recurrent pattern in the data: mothers treat fathers' answers to nurses' questions, and nurses' topicalising turns addressed to fathers, as inadequate by elaborating on the topic at issue (cf. Stivers and Heritage, 2001: 158-161). In their elaborations, mothers may highlight fathers' secondary role in childcare. Extract 3 illustrates these cases, and here the mother even starts to answer verbally on behalf of the father.

Before the beginning of Extract 3 the mother has first answered the nurse's opening question by talking at length about problems such as tiredness, and has then changed the topic by describing how the one-month-old baby slept for a three-hour period during the previous 
night. At lines 3-4 the nurse initiates talk about the father's role in childcare. We focus on the mother's answer at lines 6 and 8-9.

\section{Extract 3 (ch7, baby one month old)}

1 M: Et iha hyvihän se meni.

So it went quite well after all.

$3 \quad \mathrm{~N}: \quad J a$ sä (oot) (.) pystyny myös olee And you (have) (.) also been able to take part in

$4 \quad \mathrm{~N}: \quad[(1.0)$

[täs (.) hoitamises [mukana, [(1.0) ((gazes at F, nods)) [this (.) caring,

$5 \quad((\mathrm{M}$ gazes at $\mathrm{F} / \mathrm{B}$, nods; F's face is not visible $))$

$6 \quad \mathrm{M}: \rightarrow$

$$
\begin{array}{r}
\text { [hh ((smiles)) [ } \quad \begin{array}{l}
\mathrm{O}:[\mathrm{n}(\mathrm{vi}-) \\
\text { has (last) }
\end{array}
\end{array}
$$

[He ha: $[$ s (las-)

$7 \quad \mathrm{~F}:$

[@个Juu,@

[@个Yes,@

$8 \quad$ M: $\rightarrow$ Viime yönä Petri (0.2) hoisi hyvin kyllä. last night Name took.care well indeed

Last night Petri (0.2) took good care ((of the baby)) indeed.

$\rightarrow=($ Sää/Se:) (.) molemmilla kerroilla nosti >pystyyn ku< you/he both times he.picked up when $=($ You/He: $)$ (.) both times picked the baby >up when $<$

.h sitä siis on että tota .hhmt syönnin jälkeen se on pakko nostaa pystyy, .h that there is that you know .hhmt after eating she has to be picked up,

In this extract we see a question by the nurse (lines 3-4) that includes some of the ways of invoking gendered presuppositions discussed in the previous section: the nurse topicalises the father's role in childcare with a yes/no declarative, which implies a presupposition (see Heritage, 2010: 47-49) that the father has been able to participate in taking care of the baby. Although the father's role has not been mentioned during the previous discussion, he has confirmed some of the reporting by the mother, and the mother has gazed at the father while describing the previous night. These actions by the parents suggest that the father has at least some epistemic access (Heritage and Raymond, 2005) to the topic at issue. Thus the question suggests that the father's role in childcare is at some level expected, although not selfevident. The question addresses his role in childcare at a very basic level - not his feelings and thoughts about everyday life with a newborn, or about combining paid work and family 
life, but his ability to participate in childcare, highlighted with the verb 'take part in' combined with the modal verb 'be able to'.

Our main focus is on the mother's answer to the question. She begins to answer verbally before the father does so by repeting the verb (line 6), which suggests that new information is provided in the answer (Sorjonen, 2001: 72). As the mother has already confirmed the presupposition before the father begins to answer, an adequate response from him is to confirm her answer. Slightly after the mother, he does so with the response particle ' juu' (line 7).

In addition to confirming the presupposition in the question on the father's behalf, the mother gazes at him and goes on to give a more detailed description of the situation in which he has participated in childcare. She uses his name and the third person when describing his actions (lines 8-9) ${ }^{1}$, and in this way she addresses her talk to the nurse, although at the same time she is gazing towards the father and the baby, who is on his lap. The mother assesses the father's behaviour during the night before, thus changing the time frame offered by the nurse. Further, there is no indication in the mother's turn of the father's caring being repeated on other occasions. This implies that she only partly agrees with the presupposition invoked by the nurse's question. This is reinforced with the turn's final particle 'kyllä' (line 8), which seeks to convince the recipient (Hakulinen, 2001a: 192-193). Stating explicitly that the father does not participate would be problematic for the family, as the institution encourages fathers to participate in childcare. Highlighting the father's active role therefore presents the family in a positive light, but consequently the mother sets herself up as the representative of the family who is also accountable to the nurse for the childcare arrangements. Overall, on the one hand the mother's positive assessment produces an image of the father as a competent carer - at least in terms of the previous night. On the other hand, it positions the father as the object of an assessment, and the mother as the competent expert who is able to assess whether the father takes care of the baby correctly and sufficiently.

\section{Parents show orientation to gendered presuppositions not invoked by}

\section{nurses}

So far we have presented cases in which the gendered presuppositions are invoked by the nurse. In some cases, however, the parents may invoke the gendered presuppositions themselves: they may describe that they are sharing childcare responsibilities but refer to this activity in a way that implies orientation to the gendered presuppositions. These cases are illustrated by the following extract, in which the mother states that she does not have as much knowledge as the father over the issue the nurse has asked about; however, instead of simply letting the father answer, she accounts for her unknowing status. In Extract 4, the nurse and parents are standing around the baby-care table, and the nurse is examining the baby. She has undressed the baby and is just taking the nappy off. At line 3, the father initiates the topic of the baby urinating a lot. We focus on the mother's turns at lines 14 and 17. 


\section{Extract 4 (ch2, baby one month old)}

$1 \quad((\mathrm{~N}$ takes the nappy off $))$

$2 \mathrm{~N}: @ \mathrm{Nii}, @$

@Yes,@

3 F: Pissaa tulee aika hyvi,

He pees quite a lot,

$4 \quad \mathrm{M}:=£ \mathrm{~N}(\mathrm{~h})$ iin tulee, $£$

$=£ Y(h)$ es he does, $£$

$5 \quad \mathrm{~F}: \quad=$ Sitä tuntuu

$=$ It seems

$6 \mathrm{~N}: \quad \mathrm{No}<(0.2) \quad\left[{ }^{\circ} \mathrm{se}\right.$ on $^{\circ}$

Well< $(0.2)\left[{ }^{\circ}\right.$ it is ${ }^{\circ}$

$7 \quad \mathrm{~F}: \quad$ [(että) joka (.) kerta ku vaipan vaihtaa ni on (.)

[(that) every (.) time when one changes the nappy there is (.)

$8 \quad$ oikein tosi paljon.

really a lot.

$9 \quad \mathrm{~N}:$ Just.

Right.

$10 \quad(0.2)$

11 N: Joo, =No toisaalta se on (0.3) kertoo siitä että (1.0) (-) maitoo

Yeah, =Well on the other hand it is (0.3) ((it)) shows that (1.0) (-) (there is) milk

12 (on iha) >riittävästi.< Kuinkas useesti hän kakkaa,

(quite) >enough.< How often does he pooh,

13 (1.8) ((N gazes at the baby; M \& F turn to gaze at each other at the same time))

14 M: $\rightarrow$ Voi [voi,

oh oh

Oh [dear

$15 \quad \mathrm{~F}: \quad[\mathrm{No}<$

[Well<

16

(0.6) ((N gazes at the baby; $\mathrm{M} \& \mathrm{~F}$ gaze at each other $))$

17 M: $\rightarrow$ Sä vaihdat vaippaa (enemmä) (.) Sano [£s(h)ää£

you change nappy more say you

You change the nappy (more) (.) $£ Y(h) o u £[t e l l$ 
sanosin =Kerran päivässä, say =Once a day,

F: Nyt aina[kin että,

Now at [least so,

M:

[Nii, [Yeah,

$\mathrm{N}: \quad=$ Nii. (.) Että vielä kuitenki.

=Right. (.) So still ((that often)) nevertheless.

At line 12, the nurse asks a follow-up question related to the baby's bowel movements. The question is designed in such a way that either of the parents might answer it. While asking the question and afterwards, the nurse gazes at the baby on the baby-care table; thus the direction of her gaze is neutral in the sense that it does not address either of the parents as the principal respondent (Tiitinen and Ruusuvuori, 2012).

We focus on the mother's response, in which she treats her own lack of knowledge as problematic - although the nurse has not addressed the question particularly to her - and states that the father knows the answer. During the gap following the nurse's question, the parents turn to gaze at each other, and they both start to answer almost at the same time at lines 14 and 15. The father begins his answer with 'well', which might initiate an answer to the question, whereas the mother treats her own inability to answer the question as problematic by saying 'oh dear'. The father stops his answer short, and the parents gaze at each other in silence for a while (line 16). The nurse is still looking at the baby, and thus is not addressing either of the parents at this point either. The mother initiates an account, explaining why she does not know the answer and the father should answer (line 17). She also explicitly addresses the father as the more eligible respondent, and suggests the delicacy of this by laughing slightly during the word 'you', which refers to him (see Haakana, 2001). In sum, in this extract the nurse poses a neutral question that either of the parents might answer, and the mother shows orientation to the gendered presupposition that the mother should know about issues related to childcare - although at the same time she suggests that the parents are indeed sharing childcare responsibilities.

\section{Deviating from presuppositions of gendered parenthood}

The presupposition of mothers' primacy in relation to responsibility for childcare is a typical pattern in child health clinics, but this pattern is also often deviated from. Gendered presuppositions may be undermined or not invoked at all, as we will see in Extracts 5 and 6 . 


\section{Parents undermine gendered presuppositions}

There are several cases in the data in which the parents undermine gendered presuppositions invoked in the nurses' turns. For example, in Extract 5 the father treats the nurses' questions about his participation in childcare as presupposing something that is self-evident.

In Extract 5 the father has just finished dressing the baby and has handed him over to the mother, who is sitting near the nurse's desk. The father is walking away from the baby-care table towards the waste bin, a used nappy in his hand. The nurse has been making notes of the measurements. As the father is passing her desk, she finishes writing, lies back on her chair, gazes at him and asks him a question (line 2).

\section{Extract 5 (ch5, baby one month old)}

1 M: Meinaako [hermostu-

Are you about to [get nervo- ((about the grizzling baby))

$2 \quad \mathrm{~N}: \rightarrow$

$$
\begin{array}{ccc}
\text { [Ootkos sää ollu kaksin }(0.3) \\
\text { have-Q } & \text { you-SG been by.yourselves }
\end{array}
$$

[Have you been alone (0.3) ((N \& F gaze at each other))

3 .hh pienen miehen ${ }^{\circ}$ kanssa $\left[(\text { vielä })^{\circ}\right.$

$$
\text { little man with yet }
$$

.hh with the little ${ }^{\circ}$ man $\quad\left[(y e t)^{\circ}\right.$

$4 \quad \mathrm{~F}: \rightarrow$

$$
\begin{gathered}
{[\mathrm{Jo} \uparrow \mathrm{o}: \downarrow>(\mathrm{me}) \text { olimme tossa } \mathrm{ku}<} \\
\text { yes we were there when } \\
{[\text { Ye } \uparrow: s \downarrow>(\text { we }) \text { were there when }<}
\end{gathered}
$$

$5 \quad(0.3)((\mathrm{F}$ puts the nappy into the waste bin $))$

6 M: Yhen kerra $£$ heh [heh he he he he£

Once £heh [heh he he he he£

$7 \quad \mathrm{~F}$ :

[Yhen kerran me oltiin [(sillo)

[Once we were $[($ then $)$

$8 \mathrm{M}$ :

[£Kaks kertaa he [he he he heh£]

[£Twice he [he he he heh£]

9 F:

[Kaks kertaa ol]laan

[Twice we ha]ve been

10 oltu ihan kahestaan [että

just the two of us [so

$11 \mathrm{~N}: \quad[\mathrm{Joo}$,

[Yeah, 
$\mathrm{N}: \rightarrow$ Ootte pär $^{\circ} \mathrm{jänny} .^{\circ}$

you-PL.have managed

\section{You have ma ${ }^{\circ}$ naged. ${ }^{\circ}$}

$13 \mathrm{~F}: \rightarrow\left[\mathrm{Ju} \uparrow \mathrm{u}:\left[\downarrow \mathrm{me}:\right.\right.$ tullaan hyvin juttuun $\left[{ }^{\circ}\right.$ ei meillä mitää, ${ }^{\circ}$

yes we get fine along not we.have nothing

[Ye $\uparrow: s\left[\downarrow\right.$ we: get along fine $\quad\left[{ }^{\circ}\right.$ we have nothing, ${ }^{\circ}$

14 B: [yy

$15 \quad \mathrm{M}: \quad[(--)$

$16 \mathrm{~N}: \quad[\mathrm{Joo}$,

[Yeah,

$17 \mathrm{~N}: £$ Nii [siltä se näyttääki [et(h)tä£

$£$ Yeah [it looks like it $\quad[$ tha $(h) t £$

F:

[Toine oli

[Nii: ei [meillä =Meillä on $((\ldots))$

[The other was

[Yea:h [we have no $=$ We have $((. .)$.

19

$\mathrm{N}$ :

[£.Joo£

$[£$. Yeah£

In this extract the nurse poses two questions (at lines 2-3 and 12) addressed to the father topicalising his participation and thus treating it as not self-evident. The father's answers, on the other hand, share elements that suggest an orientation to the questions as presupposing something self-evident. His answers are immediate, provide confirmation rather than affirmation (see below), and have a marked intonation.

At line 4, the father answers without delay, overlapping with the question. An agreeing minimal response to a yes/no interrogative like that at lines 2-3 can be given in two basic ways in Finnish: by repeating the verb, or by using the response particle 'joo' (Sorjonen, 2001: 37-56; Hakulinen, 2001b; see Heritage and Raymond, 2012, and Raymond, 2003, for responses to polar questions in English). Repeating the verb would offer an affirmation, i.e. it would suggest that new information is provided in the answer (Sorjonen, 2001: 37). The father's answer, however, begins with 'joo', and in this way suggests a confirmation rather than an affirmation, i.e. that the answer does not provide new information (Sorjonen, 2001: 45-53). A marked prosody in the response is in line with these lexical and sequential features conveying that no new information is provided: the intonation figure of the answer is first a low tone, then a high tone towards the end of 'joo' (marked with an upwards arrow), and then again a lower tone at the beginning of '(we)'(marked with a downwards arrow). Ogden, Hakulinen and Tainio (2004) have demonstrated that this kind of stylised figure in Finnish marks as obvious something that has previously been said (in this case, the question).

The same intonation figure is observable in the answer (line 13) to the later question. After the confirming response particle 'juи', the father says 'we get along fine', which is an upgraded version of what was presupposed in the question (see also Stivers and Hayashi, 
2010). 'Getting along fine' implies that the father has a relationship with his son; he is not merely surviving/managing with him. He also uses the present tense, which highlights an ongoing relationship as opposed to the occasional periods alone with the baby that were the focus of the nurse's question. Both the stylised intonation figure (line 13) and the upgraded description in the present tense (line 13) show that the father treats the question as presupposing something that is obvious.

By orienting to the questions as enquiring about something that is self-evident, the father undermines the gendered presuppositions embedded in them. The mother, on the other hand, treats the information given by the father as inadequate (as in Extract 3). At lines 6 and 8, she adds the exact number of times the father has been alone with the baby - that is, when she has been away from the baby. She makes sure to note that she has only been away once or twice, thus making herself accountable for her absences and for leaving the father alone with the baby. By laughing at a point where there is no indication of humour, she marks that there is something problematic in the discussion (see Haakana, 2001). Thus although the father undermines the gendered presuppositions, the mother seems to be reinforcing them.

\section{Nurses presuppose and parents describe shared parenting}

Although nurses' questions are typically designed to presuppose a secondary role for the father, there are cases in which nurses pose questions that invoke presuppositions of shared parenting. Extract 6 below is one of these cases. In their responsive turns, the parents also describe that they share childcare responsibilities. One of the five-week-old twins has just been measured; the mother is putting the nappy on her, and the father is standing and watching next to the baby-care table. The nurse is working on the computer behind the parents.

\section{Extract 6 (ch9, baby twins five weeks old)}

$1 \quad$ F: Kyllä se äiskä on hyvä vaihtaa vaipan sulle.

Mummy is very good at changing your nappy.

2

3 F: @Nii[:,@

@Yea[h:,@

$4 \quad \mathrm{~N}: \quad[\mathrm{Mm}: ?$

5

$(0.4)$

$6 \mathrm{~N}: \rightarrow$ Onko käsialaeroja tommosissa perushommissa, are-Q handprint.differences in.those.kinds.of in.basic.tasks

Are there differences in handprints in those kinds of basic tasks,

$7 \mathrm{~N}: \rightarrow=$ Teiän välillä, =Between you, 
8 (1.0) ((the parents look down at the babies on the baby-care table))

9 F: Mi tä eroja,

Differences in what,

10 (0.6) ((F turns to gaze at $\mathrm{N} ; \mathrm{M}$ continues changing the nappy))

$11 \mathrm{~N}: \rightarrow$ Sitä että toinen tekee (0.4) erilailla [ku toine.

that that other does differently than other

That one does it (0.4) differently [to the other.

$12 \mathrm{M}:$

$[($ En mä oo< en mä oo $)$

[(I haven't $<$ I haven't)

13 sillai seurannu että (0.8)

paid so much attention to that $(0.8)$

14 F: Ei [varmaan.

I [guess not.

15 M: [että millai sää teet (mut) (0.6) @eipä nää ny kauheesti@ (0.6)

[that how you are doing (but) (0.6)@these don't really that much@ (0.6)

16 F: Ei kai niissä mitään (eroja).

I guess there are no (differences).

17

$(1.0)$

18 M: Niin ainaka lapset mitenkä protestoi

Right at least the children aren't protesting in any way

19 M: [mun mielestä [sitä (että)

$\left[^{\circ} @(\right.$ kumpi vaihtaa $){ }^{\circ}$

[ I think [in terms of $\quad\left[{ }^{\circ} @(\right.$ who is changing $){ }^{\circ}$

$20 \mathrm{~N}:[\mathrm{Mm}$,

21 F: [Iha yhtä paljon [tuottaa (.) soosia tonne.

[Exactly the same amount [of pooh is produced (.) there.

$22 \quad$ M?: £eh£

$23 \mathrm{~N}:{ }^{\circ} £$ hhhehheh ${ }^{\circ}$

24 F: [£L(h)aadussakaan ei o [niinku (0.2) eroja.£

[EEven in the quality there aren't [you know (0.2) differences. $£$

$25 \mathrm{~N}$ :

[£.hh eh .hh£ 
At line 1, the father positively assesses the mother's skills at changing the nappy. He addresses the talk to the baby by gazing at her and using the person reference 'you', and by referring to his spouse with the category term 'mummy'. The nurse offers an agreeing response particle (line 4) and asks the question we focus on here. The question 'are there differences in handprints in those kinds of basic tasks, =between you' enquires about the parents' different ways of performing childcare tasks. As the question focuses on the differences, it presupposes that both parents do basic tasks related to childcare. The nurse clarifies her question at line 11, after the father's repair initiation has marked the word 'handprint' as the problem source in the question. The reformulation of the question remains as neutral as the initial question. Referring to 'one' and 'the other', the question avoids addressing either of the parents as the one whose actions are compared to the baseline set by the other. In addition, the word 'differently' invokes no presupposition of hierarchy between the parents' actions.

Both of the parents treat the question as difficult to answer. The father repeats a negative response with two different particles displaying uncertainty, 'varmaan' and 'kai', translated here as 'I guess' (lines 14 and 16). The mother gives an account for not being able to answer by saying that she has not paid attention to how the father performs the tasks. The mother also gives grounds for her guess that there are no differences by referring to the children's reactions (line 18). The father joins in this argument and jokes about how to measure the babies' opinions: they both pooh as much and in the same way, regardless of who has changed the nappy. At line 27, the talk about sharing household tasks is continued by the father, who says that he leaves the mother to choose what the babies wear.

The extract illustrates the cases in which the nurse and the parents (at least temporarily) coconstitute parenting as shared instead of gendered. The nurse's question invokes a presupposition that both parents perform tasks related to childcare, and does not refer to either of the parents as principal or secondary. The question also suggests that there might be differences between the parents. This does not necessarily mean that the differences have to be evaluated against each other, but the parents orient to this possibility. The sequential place of the question as topicalising the father's evaluation of the mother's skill in changing the nappy might lead to this orientation. Nevertheless, the parents further treat the presupposition of the potential hierarchy in 'handprints' as irrelevant by saying that they do not pay attention to each other's performance, and by joking about it. In this way they jointly produce themselves as parents who share childcare responsibilities.

Somewhat similar orientation to producing shared parenthood is also observable in several other cases in which the parents initiate describing how sharing childcare tasks benefits their everyday life. For example, at the beginning of Extract 1 (before the nurse's question) the mother explicitly said that they have been taking turns, with the father being prepared to comfort the baby during the night (lines 4-6) as a response to the question of whether the parents have been able to sleep properly. 


\section{Discussion}

When talking about topics related to shared parenting during child health clinic encounters, nurses and parents typically invoke and orient to gendered presuppositions about parenthood. Nurses invoke gendered presuppositions by treating mothers' but not fathers' responsibilities for childcare as taken for granted. This orientation is often displayed through the topicalisation of childcare by fathers - but not by mothers - in a way that suggests that the father's role in childcare is not self-evident. Mothers may also upgrade gendered presuppositions when elaborating on fathers' answers about their participation. In addition, parents may orient to gendered presuppositions about parenthood even when the nurses have not invoked them. Thus in addition to orienting to the explicit presuppositions invoked by nurses, parents may orient to wider institutional and cultural norms about ideal or less-thanideal parenting (see Peräkylä, Ruusuvuori and Vehviläinen, 2005: 106-107; Lindfors and Raevaara, 2005: 140-142).

Although mothers are typically co-constituted by nurses and parents as the baby's principal caregivers, the encounters also provide an arena for treating gendered presuppositions as problematic, negotiating them and presupposing shared parenting. We have presented that fathers may treat questions about their participation in childcare as presupposing something that is self-evident. We have also illustrated that nurses have ways to design their questions in order to avoid gendered presuppositions and parents may describe the benefits of sharing childcare tasks. The implicit negotiations on mothers' and fathers' respective roles as parents are also observable in the cases where mothers upgrade gendered presuppositions while fathers undermine them (see Extract 5) and where parents tell about sharing childcare responsibilities but still treat it somehow accountable (see Extract 4). $\mathrm{MCH}$ encounters thus serve as an arena for discussing possibly conflicting ideals about parenthood that the participants are orienting to.

This study has focused on the sequences in which topics related to shared parenting are explicitly talked about. Future research could focus on the sequences in which parents talk about childcare and the baby without explicitly addressing topics related to shared parenting. It could analyse issues such as epistemic relations between parents, i.e. who has a right to know and tell about the baby (Heritage \& Raymond, 2005).

Discourses of mothers' primacy in childcare and shared parenting have been identified in previous research using other than interactional data (Lazar, 2000; Sunderland, 2000, 2006; Vuori, 2009). For example, Sunderland (2000) has shown that in literature aimed at parents the father's role as caregiver is still presented as secondary by comparison with mothers. In addition, Vuori (2009) has demonstrated that in texts by family professionals mothers' parenting is seen as their social duty, while fathers are left with a choice whether to take part in childcare or not. Our results are in line with these observations, but they also illuminate how these discourses are realised and reproduced in everyday interactions. Our results describe how the discourses evolve in conversation, and how they are oriented to by mothers and fathers as well as by health professionals. The present study shows how institutional and cultural understandings of gendered parenthood are co-constituted on key occasions in the discussion and negotiation of new parents' roles: in the child health clinics used by almost all families in Finland. 
While the analysis of talk-in-interaction can reveal the presence of the discourse of gendered parenthood in child health clinics, it can also describe the practices through which that discourse is realised and reproduced. By locating the recurrent patterns of interaction through which the discourse is realised, it is possible to observe where and how the discourse is challenged. Fathers' treatment of their own participation in childcare as self-evident, parents' descriptions of sharing childcare tasks and nurses' questions that presuppose shared rather than gendered parenting, are examples of such practices. Their presence may indicate an emerging change in the dominant discourse. Thus the analysis of the data indicates that child health clinics provide an arena in which not only to reproduce gendered ideas on parenting, but also to negotiate those understandings.

Gendered ideas of parenthood might be seen as problematic because they influence and potentially restrict the choices parents make with regard to sharing childcare tasks and taking parental leave, for example (see Lammi-Taskula, 2008: 142). According to Antaki (2011: $3-4)$, applying conversation analysis (CA) to the study of social problems or macro issues has been quite infrequent, with the exception of the field of feminist $\mathrm{CA}$. In the latter field various studies have shown the power of CA in unveiling gendered and heterosexist presuppositions embedded in everyday talk (Kitzinger, 2000, 2005, 2008; Land and Kitzinger, 2005; Ohara and Saft, 2003). The results of this study contribute to this line of research.

One of the targets of child health clinics is to inform parents about the benefits of shared parenting (MSAH, 2004: 84). The role of fathers both as parents and as clients in clinics has been recognised as important (MSAH, 2008). Preventive healthcare services targeted at all families with children provide an important arena for revising these gendered presuppositions, as the encounters are a place in which the presuppositions are realised and reproduced but also challenged and negotiated in and through face-to-face interaction. By analysing interactions in these kinds of institutional context we are able to uncover not only the normative institutional and cultural presuppositions, but also the fractures in them.

\section{Acknowledgements}

We would like to thank Riikka Homanen, Pirjo Lindfors and Aku Kallio for their collaboration on the research project. We are also grateful to all of the participants in the seminars and data sessions during which the analyses and earlier versions of this paper were discussed at the Universities of Tampere and Helsinki during 2010-2013, and to those who have commented on the analyses at various conferences.

\section{Funding}

This work was supported by the Finnish Doctoral Program of Social Sciences (Sovako). The data was collected as part of a research project that has received two grants from the Juho Vainio Foundation. 


\section{Notes:}

${ }^{1}$ At line 9, it is not clear whether the mother is referring to the father with the pronoun 'you' or 'he', but the verb is in third person.

\section{References}

Antaki C (2011) Six Kinds of Applied Conversation Analysis. In: Antaki C (ed) Applied Conversation Analysis. Intervention and Change in Institutional Talk. Basingstoke: Palgrave Macmillan, pp. 1-14.

Barclay L and Lupton D (1999) The experiences of new fatherhood: a socio-cultural analysis. Journal of Advanced Nursing 29(4): 1013-1020.

Eräranta K (2005) Heteroseksuaalinen matriisi ja isän vanhemmuus [The heterosexual matrix and male parenting]. Naistutkimus 18(3): 19-29.

Haakana M (2001) Laughter as a patient's resource: Dealing with delicate aspects of medical interaction. Text 21(1/2): 187-219.

Haataja A (2009) Fathers' use of paternity and parental leave in the Nordic countries. Online working papers 2/2009. Helsinki: The Social Insurance Institution of Finland (Kela).

Available at: https://helda.helsinki.fi/bitstream/handle/10250/8370/FathersLeaves_Nordic.pdf (accessed 7 June 2013).

Hakulinen A (2001a) On some uses of the discourse particle kyl(lä) in Finnish conversation. In: Selting M and Couper-Kuhlen E (eds) Studies in Interactional Linguistics. Philadelphia: John Benjamins, pp. 171-198.

Hakulinen A (2001b) Minimal and non-minimal answers to yes-no questions. Pragmatics 11(1): $1-15$.

Henwood K and Procter J (2003) The 'good father': Reading men's accounts of paternal involvement during the transition to first-time fatherhood. British Journal of Social Psychology 42(3): 337-355.

Heritage J (1995) Conversation Analysis: Methodological Aspects. In: Quasthoff UM (ed) Aspects of Oral Communication. Berlin: Walter de Gruyter, pp. 391-418.

Heritage J (2010) Questioning in Medicine. In: Freed AF and Ehrlich S (eds) "Why Do You Ask?" The Function of Questions in Institutional Discourse. New York: Oxford University Press, pp. 42-68.

Heritage J and Raymond G (2005) The Terms of Agreement: Indexing Epistemic Authority and Subordination in Talk-In-Interaction. Social Psychology Quarterly 68(1): 15-38.

Heritage J and Raymond G (2012) Navigating epistemic landscapes: acquiescence, agency and resistance in responses to polar questions. In: De Ruiter JP (ed) Questions: Formal, Functional and Interactional Perspectives. Cambridge: Cambridge University Press, pp.179-192. 
Heritage J and Sefi S (1992) Dilemmas of advice: aspects of the delivery and reception of advice in interactions between health visitors and first-time mothers. In: Drew P and Heritage $\mathrm{J}$ (eds) Talk at work. Interaction in institutional settings. Cambridge: Cambridge University Press, pp. 359-417.

Kitzinger C (2000) Doing Feminist Conversation Analysis. Feminism \& Psychology 10(2): 163-193.

Kitzinger C (2005) "Speaking as a Heterosexual": (How) Does Sexuality Matter for Talk-inInteraction? Research on Language and Social Interaction 38(3): 221-265.

Kitzinger C (2006) After post-cognitivism. Discourse Studies 8(1): 67-83.

Kitzinger C (2008) Developing Feminist Conversation Analysis: A Response to Wowk. Human Studies 31(2): 179-208.

Lammi-Taskula J (2008) Doing Fatherhood: Understanding the Gendered Use of Parental Leave in Finland. Fathering 6(2): 133-148.

Land V and Kitzinger C (2005) Speaking as a Lesbian: Correcting the Heterosexist Presumption. Research on Language and Social Interaction 38(4): 371-416.

Lazar MM (2000) Gender, discourse and semiotics: the politics of parenthood representations. Discourse \& Society 11(3): 373-400.

Leira A (2002) Updating the "gender contract"? Childcare reforms in the Nordic countries in the 1990s. NORA: Nordic Journal of Women's Studies 10(2): 81-89.

Lindfors P and Raevaara L (2005) Discussing patients' drinking and eating habits in medical and homeopathic consultations. Communication \& Medicine 2(2): 137-149.

Miettinen A (2008) Kotityöt, sukupuoli ja tasa-arvo: Palkattoman työn jakamiseen liittyvät käytännöt ja asenteet Suomessa [Housework, gender and equality: Practices and attitudes linked to sharing unpaid work in Finland]. Helsinki: Väestöliitto. Available at:

www.vaestoliitto.fi/@Bin/237612/Kotityöt+ja+tasaarvo_ebook.pdf (accessed 19 May 2014).

Ministry of Social Affairs and Health (2004) Lastenneuvola lapsiperheiden tukena. Opas työntekijöille [Child health clinics in support of families with children. A guide for staff]. Helsinki: Ministry of Social Affairs and Health.

Ministry of Social Affairs and Health (2008) Isien ja isyyden tukeminen äitiys- ja lastenneuvoloissa [Support for fathers and fatherhood at maternity and child health clinics]. Helsinki: Ministry of Social Affairs and Health.

Nentwich JC (2008) New Fathers and Mothers as Gender Troublemakers? Exploring Discursive Constructions of Heterosexual Parenthood and their Subversive Potential. Feminism \& Psychology 18(2): 207-230.

Official Statistics of Finland (2011) Time use survey. Time Use Changes Through The 2000s 2009. Helsinki: Statistics Finland. [E-publication, updated: 15 December 2011.] Available at: http://tilastokeskus.fi/til/akay/2009/05/akay_2009_05_2011-1215_tie_001_en.html?ad=notify (accessed 15 April 2013). 
Ogden R, Hakulinen A and Tainio L (2004) Indexing 'no news' with stylization in Finnish. In: Couper-Kuhlen E and Ford CE (eds) Sound Patterns in Interaction: Cross-Linguistic Studies from Conversation. Amsterdam: John Benjamins, pp. 299-334.

Ohara Y and Saft S (2003) Using conversation analysis to track gender ideologies in social interaction: toward a feminist analysis of a Japanese phone-in consultation TV program. Discourse \& Society 14(2): 153-172.

Peräkylä A, Ruusuvuori J and Vehviläinen S (2005) Introduction: Professional theories and institutional interaction. Communication \& Medicine 2(2): 105-109.

Perälä-Littunen S (2007) Gender Equality or Primacy of the Mother? Ambivalent Descriptions of Good Parents. Journal of Marriage and Family 69(2): 341-351.

Pomerantz A and Fehr BJ (1997) Conversation Analysis: An Approach to the Study of Social Action as Sense Making Practices. In: Van Dijk TA (ed) Discourse as Social Interaction. Discourse Studies: A Multidisciplinary Introduction, Volume 2. London: Sage, pp. 64-91.

Raymond G (2003) Grammar and Social Organization: Yes/No Interrogatives and the Structure of Responding. American Sociological Review 68(6): 939-967.

Sacks H, Schegloff EA and Jefferson G (1974) A simplest systematics for the organization of turn-taking for conversation. Language 50(4), 696-735.

Schegloff EA (1997) Whose text? Whose context? Discourse \& Society 8(2): 165-187.

Schegloff EA (2007) Sequence Organization in Interaction. A Primer in Conversation Analysis, Volume 1. Cambridge: Cambridge University Press.

Sevón E (2011) 'My life has changed, but his life hasn't': Making sense of the gendering of parenthood during the transition to motherhood. Feminism \& Psychology 22(1): 60-80.

Sorjonen M-L (2001) Responding in Conversation: A Study of Response Particles in Finnish. Amsterdam: John Benjamins.

Stivers T and Hayashi M (2010) Transformative answers: One way to resist a question's constraints. Language in Society 39(1): 1-25.

Stivers T and Heritage J (2001) Breaking the sequential mold: Answering 'more than the question' during comprehensive history taking. Text 21(1/2): 151-185.

Sunderland J (2006) 'Parenting' or 'mothering'? The case of modern childcare magazines. Discourse \& Society 17(4): 503-527.

Sunderland J (2000) Baby entertainer, bumbling assistant and line manager: discourses of fatherhood in parentcraft texts. Discourse \& Society 11(2): 249-274.

Tiitinen S and Ruusuvuori J (2012) Engaging parents through gaze: Speaker selection in three-party interactions in maternity clinics. Patient Education and Counseling 89(1): 38-43. 
VISK = Hakulinen A, Vilkuna M, Korhonen R, Koivisto V, Heinonen TR and Alho I (2004) Iso suomen kielioppi [Extensive Finnish grammar], online version. Helsinki: Suomalaisen Kirjallisuuden Seura. Available at: http://scripta.kotus.fi/visk (accessed 6 June 2013).

Vuori J (2009) Men's Choices and Masculine Duties: Fathers in Expert Discussions. Men and Masculinities 12(1): 45-72.

\section{Author biographies:}

Sanni Tiitinen is a doctoral student in social psychology at the University of Tampere. Her research interests include gender roles and multimodal interactions between professionals and clients in healthcare encounters. Her conversation-analytic thesis focuses on interactional practices of family support in maternity and child health clinics.

Johanna Ruusuvuori is a professor of social psychology at the University of Tampere. Her research interests include interaction between professionals and clients in healthcare settings and the achievement and loss of intersubjectivity of hearing-impaired people in clinical, everyday and work-life settings. She has published on empathy in healthcare consultations, the organisation of the gaze in doctor-patient interactions, and facial expressions in relation to spoken interaction in everyday conversation.

\section{Appendix}

Transcription symbols (see for example Schegloff, 2007: 265-269; Sorjonen, 2001: 291-292):

$\begin{array}{ll}{[]} & \text { the beginning and end of overlapping talk } \\ = & \text { no silence between two utterances } \\ (.) & \text { micropause, less than } 0.2 \text { seconds } \\ (0.4) & \text { silence of } 0.4 \text { seconds within an utterance or between two utterances } \\ ? & \text { rising intonation } \\ , & \text { continuing intonation } \\ & \text { falling intonation } \\ : & \text { the stretching of a sound } \\ \text { word } & \text { emphasis } \\ \text { o o } & \text { quiet talk } \\ - & \text { a word cut short } \\ \uparrow \downarrow & \text { rise/fall in pitch } \\ >< & \text { faster talk } \\ <> & \text { slower talk } \\ £ & \text { smiley voice } \\ @ & \text { animated voice } \\ \text { hh } & \text { in-breath } \\ \text { hh } & \text { out-breath } \\ \text { (h) } & \text { out-breath within a word, typically laughter }\end{array}$


(-) talk that is heard indistinctly

(word) uncertainty in the transcription

$((--)) \quad$ author's descriptions of events or notes clarifying the meaning of an utterance if not transparent in the transcript

$((\ldots)) \quad$ the utterance continues

In addition, in the middle lines indicating the word order in transcript lines on which we focus, we use the following abbreviations (see Sorjonen, 2001: 293):

$\begin{array}{ll}\text { SG } & \text { singular } \\ \text { PL } & \text { plural } \\ \text { Q } & \text { interrogative }\end{array}$

